O. Nakonechnyi

Ivan Chernyakhovsky National University of Defense of Ukraine, Kyiv, Ukraine

\title{
MATHEMATICAL MODEL FOR FORECASTING THE STATE OF A LOGISTICAL SYSTEM OF STATE DEFENSE
}

\begin{abstract}
Annotation. The experience of the history of wars and war conflicts shows that in every successful military company, operation, battle, as in every defeat, it is necessary, among other reasons, to look for the positive and negative sides in the work of logistical bodies, their organizations, capabilities and ways of providing. The development of the logistics system has always been carried out in parallel with the development of the armed forces and methods of warfare, operations and combat. New types of weapons, military equipment, methods of warfare put forward their requirements for the logistics system, forced to produce more modern forms of organization of the logistics system and methods of security. The system of logistical support of the state defense forces is a complex, multi-level structure. In the course of the article, the author developed a mathematical model for predicting the state of the logistical support system of the state defense forces. This model allows to predict the effectiveness of the system of logistical support of the defense forces of the state, with both the system as a whole and its individual elements. This model allows to predict the state of the logistics system, to establish relationships between individual elements of the logistics system of the defense forces of the state, to determine the number of logistics that need to be put in the near future. In the course of the research, the author used both general scientific and special methods of research: semantic was used for the development of the essential part of the definitions of the categorical apparatus of military logistics; methods of economic analysis were used to assess trends in the military provision of the Armed Forces of Ukraine; systematic analysis methods were used to evaluate the prerequisites and integrate the goals in the process of forming a military logistics system; methods of economic and mathematical modeling were used to optimize the structure and internal processes of the military logistics system. According to the results of the research, the author was tasked with developing a methodology for assessing the effectiveness of the system of logistical support of the state defense forces.
\end{abstract}

Keywords: logistics system; state defense forces; efficiency; forms and methods.

\section{Introduction}

Considering the presence of an objective constraint on reforming the Armed Forces of Ukraine, it is typical in the context of the theory of change management (conservatism, resistance to change), it is necessary to acknowledge the lack of theoretical developments in optimizing the ways of reforming the Armed Forces of Ukraine, above all their logistics.

When the business concept of logistics is increasingly perceived as one of the most effective tools for increasing competitiveness at the expense of cost advantages, in terms of elasticity and reliability, this is not always the case in the military sphere.

Logistics is the planning and implementation of the deployment and provision of troops (forces) that is applicable to aspects of military operations, which are related to the following activities: design, development (modernization and modification), purchase, storage, transportation, distribution, maintenance and repair, evacuation and disposal of material resources; transportation of personnel; purchase (construction), maintenance, operation and sale of military installations; purchase or provision of food, bath and laundry services; health care, etc. The organization of the logistics system of the Armed Forces of Ukraine envisages the widespread use of the products of production of enterprises of the state industry.

The aforementioned system is not autonomous and self-sufficient, it is embedded in the general economic processes of the state and it is prone to influence not only crisis phenomena in the economy, but also transformations occurring in the system of public administration [1-5].
The system of logistical support of the state defense forces is a complex, multi-level structure. It requires taking into account different in origin, units of measure of performance evaluation and forecasting of its status for a certain amount of time ahead.

Given the above, an urgent scientific task is to take into account the maximum number of indicators by which the system of logistical support of the defense forces of the state and the forecasting of its state is evaluated [6-14].

The purpose of this article is to develop a mathematical model for predicting the state of the logistics system for the defense forces of the state.

\section{Outline of the main research material}

One of the main research areas for the Logistics Support System of the State Defense Forces (LSSSDF) is now considered to be the development and application of models that allow to analyze and describe the process of logistical support (LS) with sufficient completeness and correlation and, on that basis, to offer methods of enhancement of its effectiveness [11].

The research of the parameters of LSSSDF functioning in the predicted conditions of their application, which is revealed by a number of contradictions in the theory and practice of LS at the present stage [12]. Among the most significant, such contradiction are mentioned: between the planned and real-time costs of organizational and theoretical tasks in the course of deciding on LS (planning of transportation of material resources); between the need to predict the need for material resources (MR) and the imperfection of the accepted scientific and methodological apparatus for forecasting. 
The essence of these contradictions should be explained.

1. Logistical support of troops in the course of the operation is organized on the basis of the analysis, which was received from the bottom-up logistics authorities of the reporting documents. The timing of their development and submission to the senior management bodies is strictly regulated, but at the same time they imply a certain information delay (time for processing and generalization of data at each of the higher levels of management).

Considering the time for tasking the contractor (military unit or logistical unit) and processing of this task, such an information delay is usually at least 2 hours. In addition, depending on the distance of the warehouses-suppliers, their equipment devices of mechanization of loading and unloading works, accessible loading front, the state of the road network, the ability to transport the truck, the influence of the enemy and other factors may delay the delivery [12-15].

As a result, until the actual delivery $(t)$ the claimed amount of material at the time of application $(t)$, the actual need is increasing: $Q(t)-Q(t)+Q(t-t)$ and it is not completely satisfied (there is a shortage $(\Delta Q)$, which is equal to the amount of costs and losses of material resources for the period of delayed delivery).

2. The organization of logistical support of troops during the operation necessarily requires the solution of the task of forecasting the need for material resources for its further management.

Known techniques are based on the estimation of the mathematical expectation (ME) of the average daily consumption of material resources, the intensity of warfare over the operation periods, the location, the role of a particular connection (part, unit) in the operational construction (combat order), the length of time of execution combat task in a given mode, etc. ME is calculated on the basis of a certain set of coefficients. These forecasting techniques (sets and values of coefficients) were developed on the basis of large-scale strategic operations and exercises of the XX century without the necessary detail on the various forms and methods of action of the troops.

In recent years, the forms and methods of combat operations have changed: disappearing lines of continuous collision of groups of troops (forces), combat operations become focal and highly maneuverable, with their intensity and dynamism increasing substantially, with advanced technologies emerging in the first place the conduct of hostilities and the processes for their provision through the introduction of fundamentally new combat and support systems.

Considering the high dynamics of modern operations (combat operations), the search for adaptive forecasting methods is especially relevant.

The use of statistical forecasting methods can help to overcome the contradictions, which are described above in the operation of the ME [11-14].
One of the main statistical methods is the variable mean method, which is described in detail in the works [11-14].

The estimated value for the planned period is the average value for $N$ previous periods.

The projected need (cost and loss) of the ME of the state defense forces in $T$ period is determined by the formula:

$$
Q_{t}^{\Pi}(T)=\frac{1}{K} \sum_{T=1}^{K} \sum_{i=1}^{N} Q_{t}^{\Phi}(T-1),
$$

where $Q_{t}^{\Pi}(T)$ is the need of the defense forces of the state, which is predicted by the $i$-th type of material devices in the period (time, day) of the operation, units of account, $\mathrm{t} ; K$ is the number of observation periods; $N$ is the nomenclature of the material devices; $Q_{t}^{\Phi}(T-1)$ is the actual consumption of material resources of the state defense forces in the previous period, units of account, $t$.

However, the method of variable average is characterized by significant shortcomings, the presence of which makes use of it while planning the logistics of troops during the operation, which is impractical.

Firstly, the use of the method requires a sufficiently long history of observations from previous periods (usually 5-6 times the duration of the forecast period).

Secondly, the method does not take into account the effect of preservation (aging) of information within a time period or statistics when the situation changes.

As a result, it is proposed to use adaptive statistical forecasting methods based on exponential smoothing as a basis for short-term forecasting of costs and losses of material resources under the considered conditions.

The scheme of construction of the adaptive forecasting model, which is presented in Fig. 1.

Mathematical modeling. Suppose that the time series model looks like

$$
y_{t}=a_{1}+\varepsilon_{1},
$$

where $y_{t}$ is the value of the time series at time $t$; $a_{1}=$ const; $\varepsilon_{1}$ is the random deviations with zero mathematical expectation and variance $\sigma^{2}$.

Expotential smoothing of a series is carried out by the formula:

$$
S_{t}=\alpha y_{t}+\beta S_{t-1},
$$

where $S_{t}$ is the exponential mean value at time $t ; \alpha$ is the smoothing parameter,

$$
\alpha=\text { const }, 0<\alpha<1 ; \beta-1-\alpha .
$$

Exponential average $S_{t}$, can be represented by the previous values of the time series, using the expression consistently (2):

$$
\begin{gathered}
S_{t}=\alpha y_{t}+\beta S_{t-1}=\alpha y_{t}+\beta\left(\alpha y_{t-1}+\beta S_{t-2}\right)= \\
=\alpha y_{t}+\beta S_{t-1}+\beta S_{t-2} .
\end{gathered}
$$

In the end we get 


$$
S_{t}=\alpha \sum_{t=0}^{n-1} \beta^{t} y_{t-i}+\beta^{n} S_{0},
$$

where $n$ is the length of the row; $S_{0}$ is the exponential mean value at the previous period of time.

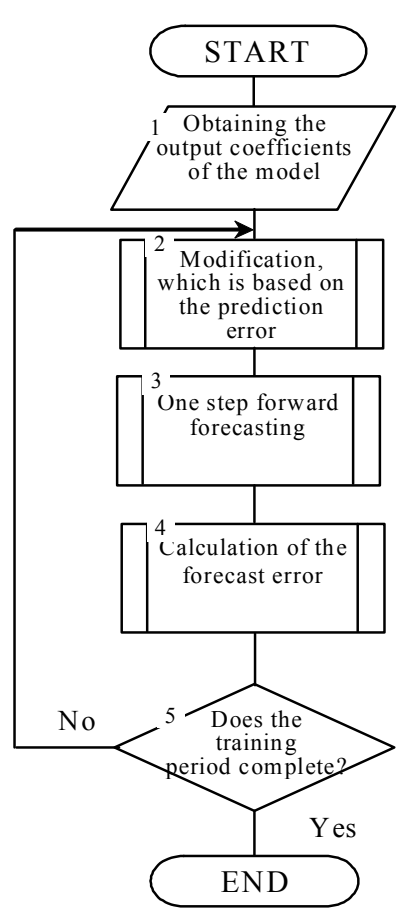

Fig. 1. An algorithm for an adaptive prediction model

Thus (3), the value $S_{t}$ is the sum of all the members of the series.

Moreover, the weights of the individual levels of the series decrease as they are removed in the past according to the exponential function. For example, when $\alpha=0,3$ (the weight of the current observation), weight of the previous level $\left(y_{t-1}\right)$ will respond $\alpha \beta-0,3 \cdot 0,7=0,21 ;$ for the level $y_{t-2}$ the weight will be $\alpha \beta^{2}=0,147$ etc.

While calculating the exponential value $S_{t}$ at time $t$ the exponential mean at the previous time is always needed $S_{t-1}$ (2) or at the first step $S_{0}$ (3). If there is a history of observations of the actual value of this indicator before the beginning of the alignment, then as the initial value of the exponential mean, you can use the arithmetic mean of all available values of the time series or any part of it. In the absence of such data, the initial value $S_{0}$ should be anticipated based on prior knowledge of the process.

The main task of optimizing the exponential smoothing model is to find the optimal value of the smoothing parameter $\alpha$. Indeed, when $\alpha=0$, the model will be characterized by a complete lack of adaptation: $S_{t}-S_{t-1}$ and when $\alpha=1$, the forecast for any time period becomes equal to the current actual value of the series. As a rule, it is recommended to take the values within $0,1-0,3$ [12], at the same time, the best values of the forecast can be reached at any acceptable values $\alpha$ [13].

Short-term forecasting using the exponential mean, which is performed according to the formula [11-14]:

$$
S_{t+1}=S_{t}+\alpha\left(y_{t}-S_{t}\right) \text {. }
$$

The new forecast $S_{t+1}$ is obtained as a result of adjusting the previous forecast to account for its error $\left(y_{t}-S_{t}\right)$. That is the adaptation of the model.

It is advisable to take the value of the $\alpha$ parameter to a large extent, taking into account fresh information.
As the forecasting period increases, on the contrary, the latest data reflecting the so-called fluctuations in the situation should be slightly less weight, this value $\alpha$ should be reduced.

The optimal parameter values $\alpha$ can be obtained by the least-squares method.

The analysis of the considered time series (Table 1) reveals a fairly pronounced trend of linear growth. While predicting the values of such a time series, the exponential mean gives a systematic error (leads to biased forecasts). Thus, the maximum prediction accuracy according to formula (4) is achieved at $\alpha=0,9$ and does not exceed $9 \%$. Such accuracy is not practically acceptable, so model (1) in this case is advisable to replace the model of linear growth according to the recommendations $[12,16]$.

The forecast can then be obtained by expression

$$
S_{t+1}=b_{1, t}+b_{2, t} \tau,
$$

where $b_{1, t}$ and $b_{2, t}$ are the current estimates of the model coefficients; $\tau$ is the time ahead of the forecast.

Estimation of coefficient values $b_{1, t}$ and $b_{2, t}$ is performed according to the following recurrent formulas:

$$
\begin{aligned}
& b_{1, t}=b_{1, t-1}+b_{2, t-1}+\alpha_{1} e_{1} \\
& b_{2, t}=b_{2, t-1}+\alpha_{1} \alpha_{2} e_{1}
\end{aligned}
$$

where $\alpha_{1}$ and $\alpha_{2}$ are the exponential smoothing parameters (adaptations), $0<\alpha_{1} ; \alpha_{2}>1, e_{t}=y_{t}-S_{t}$ is the forecast error.

The initial values of the coefficients $b_{1, t}$ and $b_{2, t}$ can be obtained by the least-squares method [8] as a result of solving the system of equations:

$$
\begin{aligned}
& b_{1, t} n+b_{2, t} n \sum_{i=1}^{n} t_{i}=\sum_{i=1}^{n} y_{i} \\
& b_{1}, t \sum_{i-1}^{n} t_{i}+b_{2, t} \sum_{i-1}^{n} t^{2} i=\sum_{i-1}^{n} t_{i} y_{i},
\end{aligned}
$$

where $n$ is the number of previous observation steps; $i$ is the sequence number of the observation stage; $t_{i}$ is the stage of information receipt, $\left(t_{1}=0, t_{2}=T, t_{3}=2 T\right)$;

$y_{i}$ is the actual value of the parameter, which is observed at the i-th stage of observation.

The most appropriate values of the adaptation parameters $\alpha_{1}$ and $\alpha_{2}$ are selected by the method of the least-squares.

Comparative estimates of the accuracy of forecasts for the selected time series using the model (4) at $\alpha=0,9$ and models (5) at $\alpha_{1}=0,7$ and $\alpha_{2}=0,1$ on relative indicators that are shown in Table 1.

Forecasting according to the accepted conditions was made starting from the fifth day of operation.

Let us analyze the advantages and disadvantages of this model. Exponential smoothing prediction does not require a long observation history. In addition, the model allows to take into account how the current trend 
is going to develop, rather than the trend that has developed on average over the whole analyzed period [12]. This is very important for predicting the dynamic environment of modern combat (operations). The resulting model is adaptive, that is, in the repeated forecasting cycle, it responds to the prediction error that occurred in the previous adaptation period, thus, iteratively receives each new actual point of the series.

Table 1 - Estimation of accuracy of forecasts by the relative indicators

\begin{tabular}{|c|c|c|c|c|c|c|c|}
\hline \multirow{2}{*}{$\begin{array}{c}\text { The } \\
\text { days of } \\
\text { operatio } \\
n\end{array}$} & $\begin{array}{c}\text { Average } \\
\text { daily } \\
\text { requirement }\end{array}$ & \multicolumn{3}{|c|}{ Simple exponential smoothing at $\alpha=0,9$} & \multicolumn{3}{c|}{$\begin{array}{c}\text { Expotential smoothing on the linear } \\
\text { growth model at } \alpha=0,7 \text { and } \alpha=0,1\end{array}$} \\
\cline { 3 - 8 } & $\begin{array}{c}\text { The value of } \\
\text { the forecast }\end{array}$ & $\begin{array}{c}\text { An absolute } \\
\text { forecast error } \\
\Delta t\end{array}$ & $\begin{array}{c}\text { Relative forecast } \\
\text { error } \delta_{t}, \%\end{array}$ & $\begin{array}{c}\text { The value } \\
\text { of the } \\
\text { forecast }\end{array}$ & $\begin{array}{c}\text { An absolute } \\
\text { forecast } \\
\text { error } \Delta t\end{array}$ & $\begin{array}{c}\text { Relative } \\
\text { forecast } \\
\text { error } \delta_{t}, \%\end{array}$ \\
\hline 1 & 7981 & - & - & - & - & - & - \\
\hline 2 & 7601 & - & - & - & - & - & - \\
\hline 3 & 7791 & - & - & - & - & - & - \\
\hline 4 & 7221 & - & - & - & - & - & - \\
\hline 5 & 7031 & 7264 & -233 & $-3,3$ & 7776 & $-745,0$ & $-10,6$ \\
\hline 6 & 7221 & 7054 & -167 & $-2,3$ & 6569 & 652,1 & 9,0 \\
\hline 7 & 6081 & 7204 & -1123 & $-18,5$ & 7025 & $-944,3$ & $-15,5$ \\
\hline 8 & 5701 & 6193 & 492 & 8.6 & 5719 & -18 & $-0,3$ \\
\hline 9 & 5321 & 5750 & -429 & $-8,1$ & 5382 & 60,5 & $-1,1$ \\
\hline 10 & 4941 & 5364 & 423 & 8,6 & 4984 & $-42,7$ & $-0,9$ \\
\hline 11 & 4560 & 4983 & -423 & $-9,3$ & 4598 & $-38,1$ & $-0,8$ \\
\hline 12 & 4180 & 4602 & 422 & 10,1 & 4210 & $-30,3$ & $-0,7$ \\
\hline
\end{tabular}

\section{The conclusions}

1. In this article, the author developed a mathematical model for predicting the state of the logistical support system of the defense forces of the state.

2. The essence of this mathematical model is that it will allow to predict the state of the system of logistical support of the state defense forces.

The application of this model in the logistics management system will allow to organize a planpreventive (in addition to the existing application) by nature of the MR trucking system, which will significantly reduce the volume of possible MR supply to consumers in the current conditions of operations (hostilities).

In addition, the proposed forecasting model can be used to determine the required volumes of military and operational stocks of the MR in the operational direction, depending on the expected duration of hostilities.

3. Thus, the article proposes an approach to forecast the need for $\mathrm{MR}$ in planning the logistics support of troops during (operations) combat operations using an adaptive model based on exponential smoothing of time series. Experimental researches on the example of forecasting the need for MR of the state defense forces in the course of a defense operation have shown a fairly high accuracy (within 5\%) of the proposed approach.

4. The above mathematical model is an integral part of the methodology of assessing the effectiveness of the system of logistical support of the state defense forces.

The direction of further research should be considered the development of a methodology for assessing the effectiveness of the functioning of the system of logistical support of the state defense forces.

\section{REFERENCES}

1. Instruction of the Chief of Staff Committee JP 4-0.

2. ADP 4-0 Sustainment

3. FM4-01.30 (FM 55-10).

4. Shkurko, Yu.M. (2003), "The methodological apparatus of the military-economic analysis of the construction of the armed forces", Military science and defense policy, No. 2. pp. 14-16.

5. Toporov, A.V. and Babenkov, V.I. (2016), "Justification of conceptual approaches to assessing the military-economic efficiency of the system of material and technical support of a group of troops (forces)", Questions of defense technology. Series 16: Technical means of countering terrorism. No. 9-10 (99-100). pp. 110-114.

6. Toporov, A.V., Konovalov, V.B. and Babenkov, A.V. (2017), "Justification of the military-economic efficiency of the process of delivering materiel to a grouping of troops (forces)" News of the Russian Academy of Rocket and Artillery Sciences. No. 2 (97). pp. 48-51.

7. Babenkov, V.I. and Bashkirov, D.S. (2017), "Prospective studies of the military-economic efficiency of the material and technical support of the troops". Actual problems of the development of modern science and education: a collection of international scientific-practical conference. pp. 112-113.

8. Shyshatskiy, A.V., Bashkirov, O.M. and Kostina, O.M. (2015), "Development of integrated systems and data for Armed Forces", Arms and military equipment, No 1(5), pp. 35-40. available at: http://journals.uran.ua/index.php/24140651/issue/view/1\%285\%29\%202015 (last accessed December 25, 2019).

9. Babenkov, A.V. (2016), "Methodological approaches to the military-economic substantiation and estimation of parameters of logistic processes in the system of material and technical support of troops", News of the Russian Academy of Rocket and Artillery Sciences. No. 1 (91). pp. 25-31. 
10. Nakonechnyi O. V. (2019), "Analysis of conditions and factors affecting the effectiveness of the functioning of the system of logistics of the defense forces of the state". Vol. 3(55), pp. 48- 57. DOI: 10.26906/SUNZ.2019.3.048.

11. Nakonechnyi O. V. (2019), "Integral indicator of estimation of efficiency of the system of logistic support of the state defense forces". Vol. 6(58), pp. 48- 57. DOI: 10.26906/SUNZ.2019.3.048.

12. Gorbach, S. A., Matsnev, D. V, Bogdanov, D. Yu (2011), "Scientific and methodological apparatus for assessing the effectiveness of the system material support of the Armed Forces", The military. Acad. Rep. Belarus. No. 3. pp. 44-49

13. Lukashin, Yu. P. (1979), "Adaptive methods of short-term forecasting”. Moscow. Statistics. 254 p.

14. Brillinger, D. (1980), "Time Series". Moscow. World. 536 p.

15. Guryanov, AV. and Babenkov, V.I. (2017), "Military-industrial safety of supply chains of components of the militaryindustrial complex". Electronic scientific journal. No. 7 (22). pp. $72-75$.

Надійшла (received) 30.12.2019

Прийнята до друку (accepted for publication) 19.02.2020

\section{Відомості ПРо Авторів / АвоUт тHE AUTHORS}

Наконечний Олександр Васильович - ад’юнкт, Національний університет оборони України, Київ, Україна; Oleksandr Nakonechnyi - adjunct, National Defence University of Ukraine, Kyiv, Ukraine, Ukraine; e-mail: o.nakon@ukr.net; ORCID ID: http://orcid.org/0000-0001-8854-8983.

\section{Математична модель прогнозування стану системи логістичного забезпечення сил оборони держави}

\section{О. В. Наконечний}

Анотаці я. Досвід історії війн і воєнних конфліктів показує, що у кожній успішно проведеній воєнній компанії, операції, бою, як і у кожній поразці, необхідно, поряд з іншими причинами, шукати позитивні та негативні сторони у роботі органів матеріально-технічного забезпечення, їх організації, можливостях і способах забезпечення. Розвиток системи логістичного забезпечення завжди здійснювався паралельно з розвитком збройних сил і способів ведення війни, операції $\mathrm{i}$ бою. Нові види озброєння, бойової техніки, способи ведення бойових дій висували свої вимоги до системи логістичного забезпечення, змушували виробляти більш сучасні форми організації системи логістичного забезпечення і способи забезпечення. Система логістичного забезпечення сил оборони держави є складною, багаторівневою структурою. В ході проведеного автором статті дослідження розроблено математичну модель прогнозування стану системи логістичного забезпечення сил оборони держави. Зазначена модель дозволяє прогнозувати ефективність системи логістичного забезпечення сил оборони держави, при цьому як системи в цілому так і окремих їі елементів. Зазначена модель дозволяє провести прогнозування стану системи логістичного забезпечення, встановити взаємозв'язки між окремими елементами системи логістичного забезпечення сил оборони держави, провести визначення кількості матеріально-технічних засобів що необхідно поставити найближчим часом. В процесі проведеного дослідження автором використані як загальнонаукові, так $\mathrm{i}$ спеціальні методи дослідження: семантичний - для розвитку сутнісної частини дефініцій категорійного апарату військової логістики; методи економічного аналізу - для оцінювання тенденцій у військовому забезпеченні Збройних Сил України; методи системного аналізу - для оцінювання передумов та інтеграції цілей у процесі формування військової логістичної системи; методи економіко-математичного моделювання - для оптимізації структури та внутрішніх процесів військової логістичної системи. За результатами проведеного дослідження автором було поставлено завдання на розробку методики оцінювання ефективності системи логістичного забезпечення сил оборони держави.

Ключов і слов а : система логістичного забезпечення; сили оборони держави; ефективність; форми та способи.

\section{Математическая модель прогнозирования состояния системы логистического обеспечения сил обороны государства}

А. В. Наконечный

Аннотация. Опыт истории войн и военных конфликтов показывает, что в каждой успешно проведенной военной компании, операции, боя, как и в каждой поражении, необходимо, наряду с другими причинами, искать положительные и отрицательные стороны в работе органов материально-технического обеспечения, их организации, возможностях и способах обеспечения. Развитие системы логистического обеспечения всегда осуществлялся параллельно с развитием вооруженных сил и способов ведения войны, операции и боя. Новые виды вооружения, боевой техники, способы ведения боевых действий выдвигали свои требования к системе логистического обеспечения, заставляли производить более современные формы организации системы логистического обеспечения и способы обеспечения. Система логистического обеспечения сил обороны государства является сложной, многоуровневой структурой. В ходе проведенного автором статьи исследования разработана математическая модель прогнозирования состояния системы логистического обеспечения сил обороны государства. Указанная модель позволяет прогнозировать эффективность системы логистического обеспечения сил обороны государства, при этом как системы в целом, так и отдельных ее элементов. Указанная модель позволяет провести прогнозирования состояния системы логистического обеспечения, установить взаимосвязи между отдельными элементами системы логистического обеспечения сил обороны государства, провести определение количества материально-технических средств, которые необходимо поставить в ближайшее время. В процессе проведенного исследования автором использованы как общенаучные, так и специальные методы исследования: семантический - для развития сущностной части дефиниций категориального аппарата военной логистики; методы экономического анализа для оценки тенденций в военном обеспечении Вооруженных Сил Украины; методы системного анализа - для оценки предпосылок и интеграции целей в процессе формирования военной логистической системы; методы экономикоматематического моделирования - для оптимизации структуры и внутренних процессов военной логистической системы. По результатам проведенного исследования автором была поставлена задача на разработку методики оценки эффективности системы логистического обеспечения сил обороны государства.

Ключевые слов а: система логистического обеспечения; силы обороны государства; эффективность; формы и способы. 